\title{
A Comparison of Skin Thickness Data from Ultrasonography with Literature Data Obtained via Histology and Magnetic Resonance Imaging: Cheek, Anterior
} Neck, and Décolleté

\author{
Patrick Micheels ${ }^{1, *}$, Stéphanie Besse ${ }^{2}$, JalilRouijel ${ }^{3}$, and Sandor Viski ${ }^{4}$ \\ ${ }^{1}$ Private practice, Chêne-Bougeries, Switzerland \\ ${ }^{2}$ Medlmage, Private RX institute, Geneva, Switzerland \\ ${ }^{3}$ Private practice, Acacias, Switzerland \\ ${ }^{4}$ Medical center, Grand-Saconnex, Switzerland
}

*Corresponding author: Patrick Micheels, Private practice, Chêne-Bougeries, Switzerland, Tel: +41 2234711 13; E-mail: patrickscab@bluewin.ch

Received: 20 May, 2020 | Accepted: 04 Jun, 2020 | Published: 10 Jun, 2020

Citation: Micheels P, Besse S, Rouijel J, Viski S (2020) A Comparison of Skin Thickness Data from Ultrasonography with Literature Data Obtained via Histology and Magnetic Resonance Imaging: Cheek, Anterior Neck, and Décolleté. J Clin Cosmet Dermatol 4(3): dx.doi.org/10.16966/25762826.152

Copyright: (C) 2020 Micheels P, et al. This is an open-access article distributed under the terms of the Creative Commons Attribution License, which permits unrestricted use, distribution, and reproduction in any medium, provided the original author and source are credited.

\begin{abstract}
Introduction: Over many years now, our team has been convinced that the injection depths indicated by authors in published studies on intradermal injection therapy are incorrect. This paper sought to compare skin thickness data derived from ultrasonography with literature data obtained via histological examination and magnetic resonance imaging.

Patients and Methods: Skin layer thickness measurements were performed on healthy subjects using ultrasound imaging technology. In each case, the ultrasound transducer was placed on the cheek, anterior neck, and décolleté, with measurements taken of the epidermis, dermis, epidermis + dermis, hypodermis, and full skin thickness. These data were compared with skin layer thickness measurements from the literature obtained via histological examination and magnetic resonance imaging.

Results: Overall, 80 healthy subjects were classified according to gender and age: 10 females and 10 males pertaining to each of the following age groups: $35-45,46-55,56-65$, and $>66$ years. The comparative histological data concerned 140 skin residues, with a descriptive histological analysis of each cutaneous area; the comparative MRI data concerned 36 healthy subjects, with only face data considered. On data analysis, the study's ultrasound measurements were close to the histological data, although the MRI results were even closer.
\end{abstract}

Conclusion: Based on this study's findings, it seems warranted that the injection techniques and definitions herein be thoroughly reviewed in order to enable care providers to properly perform their work and compare published scientific reports pertaining to this field of growing interest.

Keywords: Mesotherapy; Injection depth; Needle penetration angle; Intraepidermal injection; Superficial intradermal injection; Deep intradermal injection

\section{Introduction}

Mesotherapy, which is now called "Intradermal Injection Therapy" (IDT), was introduced in 1952 by the French physician Dr. Pistor M [1]. The term "meso" means "middle" and refers to the mesoderm, which represents the embryonic middle layer of skin located between the ectoderm and endoderm. The term "mesotherapy" refers to the treatment of medical or cosmetic conditions by the application of several intradermal microinjections of active compounds into target tissues with very fine needles and at very small doses. All the connective tissues that form the dermis are derived from this embryonic middle layer. This layer ceases to exist beyond the embryonic stage of human development. It is precisely into this middle layer that bioactive substances, such as plant extracts, pharmaceutical products, enzymes, hormones, and vitamins, are injected in an IDT setting. It is interesting to know that IDT is currently recognized by the French Health Insurance as an integral part of therapeutic modalities [2].

Whether for IDT training or for esthetic medicine designed to correct wrinkles and folds on the face, neck, or upper chest, precise instructions are always provided concerning the different depths to which the bioactive products must be injected. For esthetic purposes, depending on the viscoelastic properties of the active principles applied to correct wrinkles or loss of facial volume, the instructions for use stipulate that the agents are respectively injected into the upper, middle, or lower dermis, at times as deep as the subcutaneous 
fat or even the supraperiostal level. In the medical field, these layers are generally termed the superficial, mid, and deep dermis, in addition to fat tissues or even the supra-periosteal level. In the IDT setting, a clear-cut distinction is made between four different injection types: 1) epidermal injection, which is a mild brush of the stratum corneum rather than a true injection; 2) superficial intradermal injection, which is also referred to as nappage or picotage and is considered the gold standard of intradermal therapy; 3) deep intradermal injection, which is also referred to as a "point-by-point" technique; 4) dermohypodermal injection, which is an injection placed at a depth of 4-6 $\mathrm{mm}$, possibly up to $10 \mathrm{~mm}$.

Over many years now, our team has been convinced that the injection depths indicated by authors in published studies on IDT and esthetic medicine are incorrect. Therefore, we have previously published several papers focused on injection depths for wrinkle filling therapies [3-5].

As regards esthetic medicine, particularly for correcting the loss of facial volume, as well as for skin rejuvenation, in the form of Mesolift, Mesoglow, or other "skin boosters," this paper primarily deals with the cheek, neck, and décolleté. In a subsequent article, the focus will be on other body parts, which may be of interest in general medicine and, more particularly, in standard IDT.

The question raised again in this paper is: Do the technical terms used to refer to the injection technique actually correspond to the scientific depth of injection attained when the injection is performed? [6]. It is against this background that this study was designed and implemented. This publication sought to compare data retrieved by means of ultrasound technology with those retrieved from scientific literature based on either skin biopsies or via Magnetic Resonance Imaging (MRI).

\section{Materials and Methods}

\section{Subjects}

Initially, ultrasonographic measurements were performed in two subjects: the first a 66-year-old Caucasian woman and the second a 61-year-old Caucasian man, both with Fitzpatrick Type IV skin [7]. Next, the measurements were further refined; they involved 10 female and 10 male subjects pertaining to each of the following age groups: $35-45,46-55,56-65$, and $>66$ years, resulting in overall 80 subjects overall. Demographic data of the 80 subjects have been summarized by gender in table 1 .

\section{Ultrasonography}

Concerning the equipment applied, for the two first study subjects, the authors collaborated with the Medimage Radiology Institute in Geneva, Switzerland, using a Samsung RS80A with a Prestige ultrasound machine and Meditron 4-18- $\mathrm{MHz}$ high-resolution transducer (Meditron, Gland, Switzerland). For the other patients, a LOGIQ e imaging engine and $17 \mathrm{MHz}$ L8-18i RS linear transducer (both from GE Medical Systems, Opfikon, Switzerland) were used.

For the UltraSonographic (US) measurements, subjects were required to attend the Magellan center, Geneva, Switzerland, only once. Prior to entry, the subjects all gave informed written consent, after having received verbal and written information about the study's methodology and procedures. At least 15 days were provided to confirm their effective study participation, in line with the Declaration of Helsinki principles. The signed forms gave consent for photography and the collection of ultrasound measurements for the study's purpose. Due to the different time schedules and the required availability of both study participants and investigating physicians, the trial was carried out over a 15-month period, ranging from October 2018 to December 2019.

For all the ultrasound measurements, we used a "no touch" technique between US probe and skin, using a lot of water-based gel for the smooth transmission of ultrasound waves (Figure 1) [8].

Next, the transducer was systematically placed on the right and left areas of the subjects' skins, as follows: the cheek on either side, anterior aspect of the neck on either side of the trachea, and upper chest at the third intercostal space parasternally on either side, as illustrated in figure 2. In each area, thickness measurements were taken of the following: the epidermis, dermis, epidermis + dermis, hypodermis, as well as the total skin thickness.

This enabled us to obtain overall 160 measurements, 80 of which pertained to women and 80 to men, with precisely 20 measurements for each age group (10 left and 10 right cheeks), including each time 10 women and 10 men.

\section{Histology}

This section takes reference from the histological skin data presented by Della Volpe, C et al. in a remarkable research work on 140 skin residues adapted to plastic surgery [9]. Briefly, Della Volpe’s histological study comprised two phases. The first was a classic quantitative study consisting of measurements of each cutaneous layer and the objective evaluation of elastic density in the superficial dermis. The second was a descriptive histological analysis of each cutaneous area.

\section{Magnetic resonance imaging}

This section considers the research on MRI conducted by Aubry S, et al. [10] and Bittoun J, et al. [11], in addition to a most interesting presentation by JP Martin at the 2018 Paris conference of the French Society of Mesotherapy titled : "In-vivo MRI study of the skin: toward a new definition of mesotherapy techniques".

For skin conditions, MRI proves challenging due to the tiny structures that need to be visualized. However, by increasing the gradient amplitude or duration, skin layers can be visualized with a voxel size of 20 micron. As outlined by Bittoun J, et al. [11], the gradient strength of most commercial systems enables the acquisition of such small voxel sizes. To achieve sufficient sensitivity, the Signal-To-Noise Ratio (SNR) can be increased by minimizing noise with small coils, i.e., superconducting coils that are capable of enhancing the SNR by a factor of $\geq 3$. Using this technology, Aubry S, et al. [10] conducted a study involving 36 healthy subjects who underwent MRI of the face and calf. The data clearly revealed good visibility of the epidermis, dermis, and hypodermis, with excellent image quality, few motion artefacts, and a high intra- and inter-observer correlation (kappa coefficient of $\geq 0.84$ ). This paper takes reference from the study's MRI data obtained for the face only.

\section{Results \\ Subject population}

Overall, 80 patients volunteered to participate and all completed it. The baseline characteristics by age group have been summarized in table 1. The mean ages ranged from 42.3 to 71.2 years (Extreme: 39-82years). The groups' ages were balanced, and their Fitzpatrick skin types were representative of Geneva population. 
Table 1: Demographic data from all subjects.

\begin{tabular}{|c|c|c|c|c|c|c|c|c|c|c|c|c|}
\hline \multicolumn{13}{|c|}{ WOMEN } \\
\hline $\begin{array}{l}\text { Age } \\
\text { group }\end{array}$ & $\begin{array}{l}35-45 \\
\text { years }\end{array}$ & & & 46-55 years & & & $\begin{array}{l}56-65 \\
\text { years }\end{array}$ & & & $\begin{array}{c}>66 \\
\text { years }\end{array}$ & & $\begin{array}{c}\text { Mean age of } \\
\text { the } 40 \text { subjects }\end{array}$ \\
\hline Subject & $\begin{array}{l}\text { Age in } \\
\text { years }\end{array}$ & $\begin{array}{c}\text { Fitzpatrick } \\
\text { type }\end{array}$ & Subject & $\begin{array}{l}\text { Age in } \\
\text { years }\end{array}$ & $\begin{array}{c}\text { Fitzpatrick } \\
\text { type }\end{array}$ & Subject & $\begin{array}{l}\text { Age in } \\
\text { years }\end{array}$ & $\begin{array}{c}\text { Fitzpatrick } \\
\text { type }\end{array}$ & Subject & $\begin{array}{l}\text { Age in } \\
\text { years }\end{array}$ & $\begin{array}{c}\text { Fitzpatrick } \\
\text { type }\end{array}$ & \\
\hline 1 & 39 & III & 1 & 46 & III & 1 & 56 & $\mathrm{~V}$ & 1 & 66 & III & \\
\hline 2 & 40 & III & 2 & 48 & II & 2 & 56 & III & 2 & 66 & III & \\
\hline 3 & 40 & II & 3 & 48 & II & 3 & 56 & III & 3 & 67 & IV & \\
\hline 4 & 41 & III & 4 & 48 & II & 4 & 57 & III & 4 & 69 & III & \\
\hline 5 & 42 & IV & 5 & 49 & V & 5 & 57 & II & 5 & 70 & II & \\
\hline 6 & 42 & II & 6 & 53 & III & 6 & 57 & II & 6 & 70 & II & \\
\hline 7 & 44 & II & 7 & 53 & IV & 7 & 58 & IV & 7 & 71 & II & \\
\hline 8 & 44 & II & 8 & 53 & 1 & 8 & 62 & III & 8 & 73 & III & \\
\hline 9 & 44 & II & 9 & 54 & II & 9 & 63 & II & 9 & 76 & III & \\
\hline 10 & 45 & III & 10 & 55 & III & 10 & 65 & III & 10 & 80 & II & \\
\hline Mean & 42.1 & & Mean & 50.7 & & Mean & 58.7 & & Mean & 70.8 & & 55.6 \\
\hline \multicolumn{13}{|c|}{ MEN } \\
\hline $\begin{array}{l}\text { Age } \\
\text { group }\end{array}$ & $\begin{array}{l}35-45 \\
\text { years }\end{array}$ & & & 46-55 years & & & $\begin{array}{l}56-65 \\
\text { years }\end{array}$ & & & $\begin{array}{c}>66 \\
\text { years }\end{array}$ & & $\begin{array}{c}\text { Mean age of } \\
\text { the } 40 \text { subjects }\end{array}$ \\
\hline Subject & $\begin{array}{l}\text { Age in } \\
\text { years }\end{array}$ & $\begin{array}{c}\text { Fitzpatrick } \\
\text { type }\end{array}$ & Subject & $\begin{array}{l}\text { Age in } \\
\text { years }\end{array}$ & $\begin{array}{c}\text { Fitzpatrick } \\
\text { type }\end{array}$ & Subject & $\begin{array}{l}\text { Age in } \\
\text { years }\end{array}$ & $\begin{array}{c}\text { Fitzpatrick } \\
\text { type }\end{array}$ & Subject & $\begin{array}{l}\text { Age in } \\
\text { years }\end{array}$ & $\begin{array}{c}\text { Fitzpatrick } \\
\text { type }\end{array}$ & \\
\hline 1 & 39 & III & 1 & 46 & IV & 1 & 56 & III & 1 & 66 & V & \\
\hline 2 & 40 & $\mathrm{~V}$ & 2 & 46 & IV & 2 & 56 & IV & 2 & 66 & III & \\
\hline 3 & 42 & II & 3 & 49 & IV & 3 & 58 & II & 3 & 67 & III & \\
\hline 4 & 44 & II & 4 & 50 & III & 4 & 59 & V & 4 & 69 & III & \\
\hline 5 & 44 & IV & 5 & 50 & III & 5 & 59 & II & 5 & 69 & IV & \\
\hline 6 & 44 & $\mathrm{I}$ & 6 & 50 & IV & 6 & 61 & IV & 6 & 71 & II & \\
\hline 7 & 45 & II & 7 & 51 & II & 7 & 61 & III & 7 & 73 & II & \\
\hline 8 & 39 & III & 8 & 51 & II & 8 & 61 & IV & 8 & 74 & III & \\
\hline 9 & 45 & IV & 9 & 52 & III & 9 & 62 & IV & 9 & 79 & II & \\
\hline 10 & 43 & II & 10 & 54 & II & 10 & 62 & II & 10 & 82 & II & \\
\hline Mean & 42.5 & & Mean & 49.9 & & Mean & 59.5 & & Mean & 71.6 & & 55.9 \\
\hline
\end{tabular}

\section{Ultrasound results}

Figure 1 illustrates the different skin layers evidenced and measured via US technology. The gel coat between skin and US probe appears hypoechoic. The epidermis looks like a thin hyperechoic band, just below the hypoechoic gel coat. In certain subjects, we could identify an hypoechoic coat just under the epidermis, corresponding to the Subepithelial Low Echogenic Band (SLEB).This band proved to be more visible on heliodermic skin. In the past, several authors have claimed that this band corresponds to the papillary dermis.

The reticular dermis looks like a band with homogenous thickness, variable from one body area to another, with homogenous US features.

The hypodermis is visible as hypoechoic \& heterogenous band, owing to its fat lobules and fibrous septa, respectively. Muscles are additionally visible below the fat tissues, separated by a thin hyperechoic band that corresponds to aponeurosis tissues.
The mean data pertaining to ultrasound measurements have been summarized by age group for the face (cheek), neck (anterior face), and upper chest (décolleté) in table 2. Screen views during ultrasound measurements for the cheek, neck's anterior face, and décolleté have provided in figure 2. Figure 3 displays screen views during ultrasound imaging with precise measurements pertaining to the different skin layers.

These ultrasound results have been compared with the Della Volpe C, et al. data [9], which were acquired using histology, and those originating from Aubry S, et al. [10], which were obtained via MRI, although only for the area of face. These comparative data are being discussed in the Discussion section.

\section{Discussion}

These comparative figures clearly reveal that the study's ultrasound measurements were close to Della Volpe's histological data, though the MRI data originating from Aubry S, et al. were even closer to 


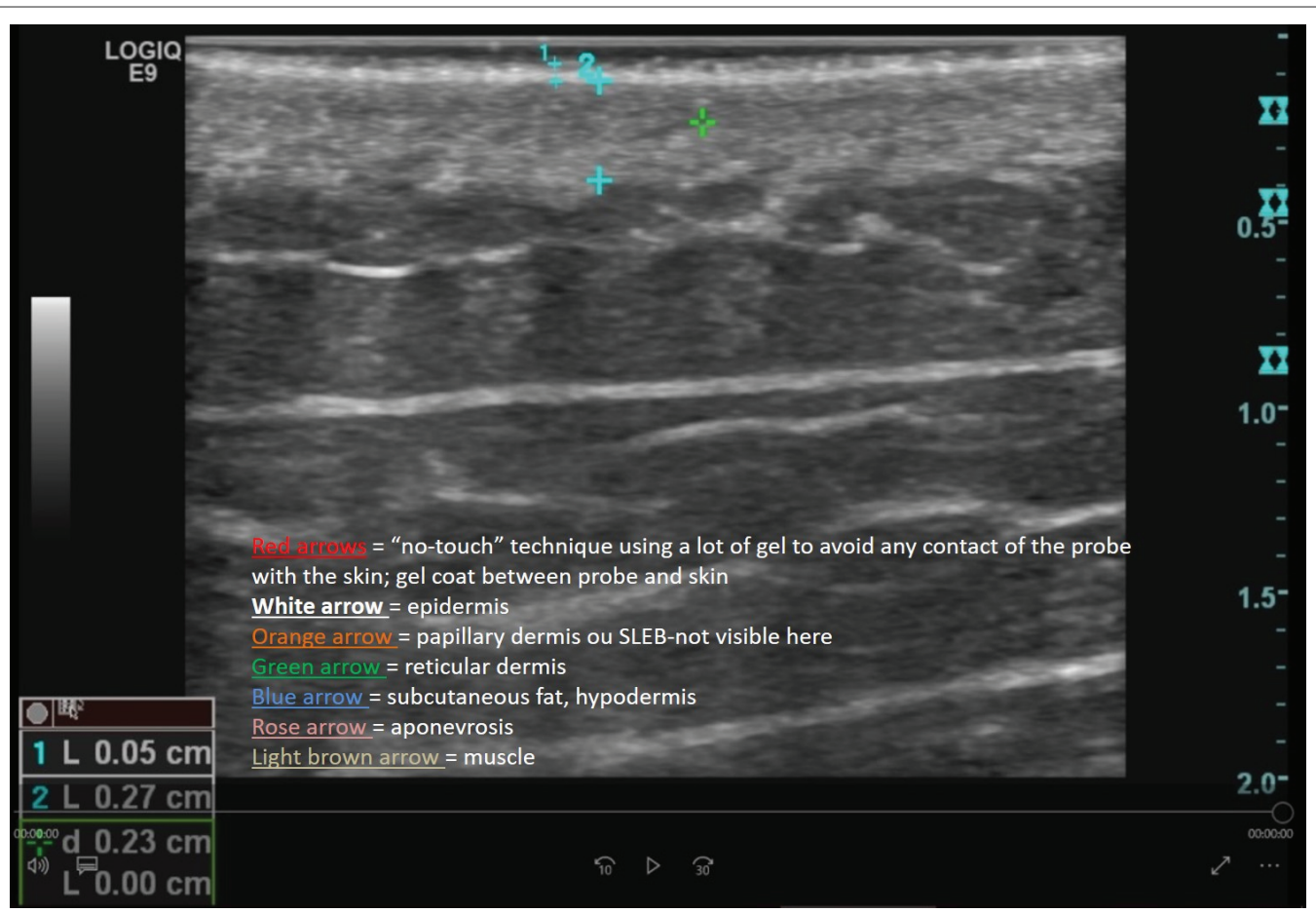

Figure 1: The "no touch" technique between US probe and skin used, with a lot of water-based gel for the smooth transmission of ultrasound waves.
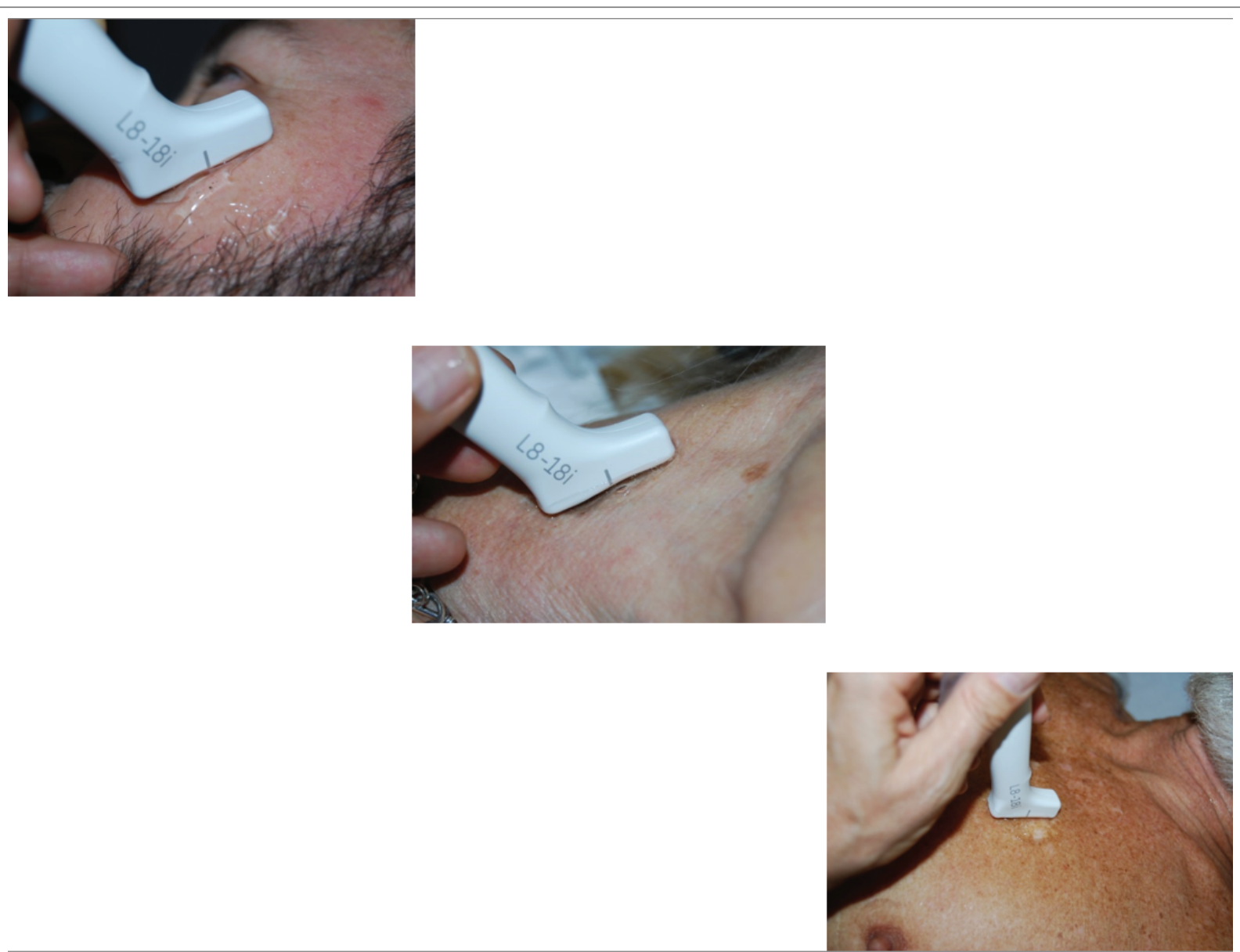

Figure 2: Views during measurements, from left to right-above: cheek; center: neck's anterior face; below: décolleté. 
these histological measurements. These differences in skin thickness depending on the technology used will be further discussed a later time point, in this section.

For this observation, we have compared histological data derived from a study designed for plastic surgeons with our US skin layer measurements pertaining to three different body areas and involving 80 subjects from our own private practice (Table 2). Here, it must be stressed that the included study population was considered representative of the Geneva general population, in terms of skin characteristics. With these data, we have additionally compared some MRI measurements originating from Aubry S, et al., concerning areas observable by this non-invasive technique.

Let us start with the histological results, involving table 3 that takes reference from the histological skin data presented by Della Volpe C, et al. in a remarkable investigation involving 140 skin residues [9]. As can be seen, the epidermis displays thickness variations depending on the anatomical area considered, with mean values varying from 0.06 to $0.16 \mathrm{~mm}$, for the neck and cheek, as well as in-between mean values obtained for the periareolar area and the remaining breast, respectively. Beneath the epidermis lies the dermis, with mean thickness variations ranging from 1.20 to $2.56 \mathrm{~mm}$ for the neck and cheek, respectively. For the study's full skin thickness involving epidermis, dermis, and hypodermis, the lowest mean value was measured for the anterior neck with $2.92 \mathrm{~mm}$, and the highest for the cheek with $4.42 \mathrm{~mm}$ (Table 3).

Considering the different skin layers, their thickness is highest at the cheek and lowest at the neck, with in-between thickness values obtained for the upper chest. Regarding the upper chest's different skin layers, their thickness is lower in the periareolar area than the remaining breast, except for the hypodermis where roughly similar thickness values were attained for the periareolar and breast areas.

When comparing the skin thickness measurements obtained using these three different techniques, the collected data vary slightly depending on the technology applied. However, what is even more astonishing and particularly relevant for healthcare professionals working in the IDT setting, is the following observation: The skin is very thin! In line with the data collected using the most up-to-date technologies, the skin is much thinner than initially anticipated. The practical impact of this observation will be further discussed below.

This comparative study clearly revealed that the skin layer measurements were slightly dissimilar, depending on whether ultrasonography, histology, or MRI was used for data collection. Upon data analysis, it was noted that the study's ultrasound measurements were close to Della Volpe's histological data, although the MRI results were proven to be even closer to histological estimations,

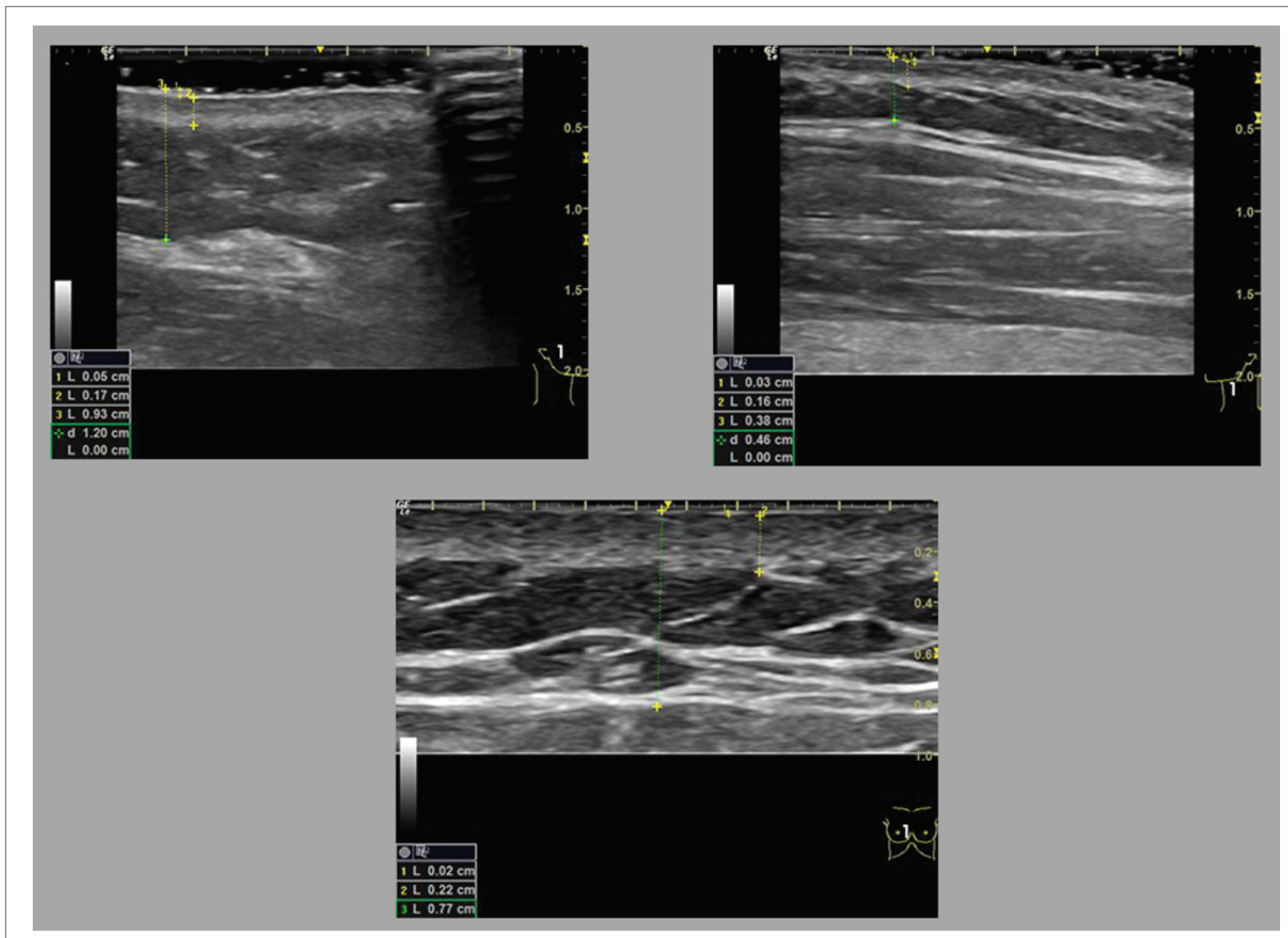

Figure 3: Screen views during ultrasound measurements, from left to right-above: cheek; center: neck's anterior face; below: décolleté. 
Table 2: Mean ultrasonographic measurements by area and gender, compared with Della Volpe's histological data and Aubry's RMI data.

\begin{tabular}{|c|c|c|c|c|c|}
\hline & $39-80$ years & $39-82$ years & $35-82$ years & Della Volpe [9] & Aubry [10] \\
\hline & Women & Men & Mean for study cohort & & \\
\hline \multicolumn{6}{|c|}{ Cheek } \\
\hline Epidermis & 0.20 & 0.20 & 0.20 & 0.16 & 0.20 \\
\hline Dermis & 1.51 & 2.07 & 1.79 & 2.56 & 1.75 \\
\hline Epidermis + dermis & 1.71 & 2.33 & 2.02 & 2.85 & 1.95 \\
\hline Hypodermis & 3.50 & 3.53 & 3.52 & 1.57 & 2.32 \\
\hline $\begin{array}{l}\text { Total skin thickness (epidermis+ } \\
\text { dermis + hypodermis) }\end{array}$ & 5.21 & 5.82 & 5.51 & 4.42 & 4.27 \\
\hline \multicolumn{6}{|c|}{ Neck anterior face } \\
\hline Epidermis & 0.19 & 0.19 & 0.19 & 0.06 & \\
\hline Dermis & 1.26 & 1.60 & 1.43 & 1.20 & \\
\hline Epidermis + dermis & 1.45 & 1.79 & 1.62 & 1.26 & \\
\hline Hypodermis & 1.70 & 2.27 & 1.98 & 0.75 & \\
\hline Total skin thickness & 3.15 & 4.06 & 3.60 & 2.92 & \\
\hline \multicolumn{6}{|c|}{ Décolleté } \\
\hline Epidermis & 0.20 & 0.20 & 0.20 & 0.10 & \\
\hline Dermis & 1.69 & 1.75 & 1.72 & 1.96 & \\
\hline Epidermis + dermis & 1.89 & 1.92 & 1.90 & 2.06 & \\
\hline Hypodermis & 5.17 & 3.81 & 4.49 & 1.87 & \\
\hline Total skin thickness & 7.06 & 5.53 & 6.29 & 3.93 & \\
\hline
\end{tabular}

Notes: In red: our US data; in blue: Della Volpe's histological data; in orange: Aubry's MRI data for the cheeks.

Table 3: Della Volpe's histological measurements of the anatomic regions explored [9].

\begin{tabular}{|l|c|c|}
\hline \multicolumn{1}{|c|}{ Thickness measured in different areas $(\mathbf{m m})$} & CHEEK & NECK anterior aspect \\
\hline Epidermis & 0.16 & 0.06 \\
\hline Dermis & 2.56 & 1.20 \\
\hline Epidermis + dermis & 2.85 & 1.26 \\
\hline Hypodermis & $1.57 / 1.96$ & 0.10 \\
\hline Full thickness Epidermis + dermis+ hypodermis & 4.42 & $1.96 / 2.06$ \\
\hline
\end{tabular}

Notes: In black: Della Volpe's data for periareolar area; in red: for the breast itself.

as demonstrated in table 2. In this regard, it must be noted that the skin retracts by itself and becomes dehydrated upon histological preparation. It must also be recalled that the literature-derived MRI sample was rather small in size, which may lead to bias. Another distinct possibility for the detected discrepancies is that the ultrasound cursor is less precise compared with both the MRI and histological cursors (Figure 4).

In this study, the ultrasound skin thickness measurements were obtained by a specialist with longstanding expertise in ultrasound technology from three different anatomical areas of 80 subjects. These three areas were precisely the zones of particular interest in esthetic medicine: the face, neck, and décolleté. Measurements were taken first on the right side, then on the left. When comparing this study's ultrasound measurements with those obtained via histology or MRI, it can be said that the data obtained using these three different tools are roughly comparable but not identical.

Irrespective of the technology applied, there is a key observation that can be drawn based on our data outcome: The skin is very thin. In line with the three skin thickness datasets obtained, the skin is thinner than initially anticipated, and thus more delicate and fragile when 
intradermal injections are being performed. This observation has thus practical consequences, particularly for health professionals working in the IDT setting. From the technical point of view, correct skin US measurements can be obtained with a "no-touch" technique by using a lot of gel to avoid any contact of the probe with the skin. This I intended to impede any pressure by the probe resulting in erroneous measurements. The anechoic layer of gel must be evident above the epidermis in the upper US image, as nicely documented in Caggiati A [8].

A first point worth mentioning is that when a needle is introduced into the skin, particularly into the epidermis and dermis, the thickness of the skin layers varies depending on the area into which the injections are made. This has clearly been evidenced by the skin layer data collected. From a practical point of view, it must be emphasized that the skin thickness is clearly lower than what has been anticipated or previously reported. This leads to practical issues in the IDT setting. Let us illustrate this further as based on our own practical experiences. Regarding intradermal injections, if the injectors sense a kind of resistance on introducing the needle into the skin, they are actually not crossing the epidermis but rather already the dermis. With a little more pressure, the hypodermis is reached.

Here, are some practical tips that have proven useful to us, enabling us to better appreciate the needle depth of intradermal injections. If the needle can be seen through the skin, the injector has likely reached the dermis, most probably the superficial dermis or, at the most, the mid-reticular dermis. If by moving the needle translationally, the fullskin tissue is being dragged along, this means that it is for sure in the dermis. On the contrary, if the needle cannot be seen through the skin, this signifies that the hypodermis has been reached. This is especially so if, by moving the needle translationally, it can be easily displaced without dragging the skin along.
Without going into further detail, the presented study findings clearly demonstrate that there is still insufficient knowledge regarding the skin's histological structures. Consequently, there exists a real need for healthcare providers to refresh their understanding of the various skin layers, as well as their contents and functions. The missing parts in this skin care field must be retrieved and put together to result in an overall holistic picture. Additionally, there is a vital requirement for them to revise the injection techniques employed, the required injection depth, and the type of substance to be used, as well as their respective designations. Concerning the bioactive molecules applied for comprehensive facial volume filling, their packaging leaflets and product characteristics necessitate a thorough review with respect to the recommended injection depths. Besides, there is a substantial lack of scientific research and evidence-based studies that have explored the safety and efficacy of IDT, and numerous questions remain about the scientific validity of this approach. Given that the IDT use for skin rejuvenation has speedily increased over the past few years, at a relatively high financial cost to patients, the leading European and American universities where IDT training sessions are delivered must keep up to date with the latest research, as the different IDT techniques and associated injection depths that are being taught require a complete overhaul.

Based on this study's findings, and as already previously reported [12], the authors wish to end this paper with a few claims. In esthetic medicine, there are erroneous assumptions regarding injection depths. This likewise applies to the majority of scientific papers that report injection depth data. The histological terms used to refer to the described injection depths are most likely wrong. Moreover, the definitions referring to injection techniques are also likely to be inaccurate. It's time to act and this, on many fronts!

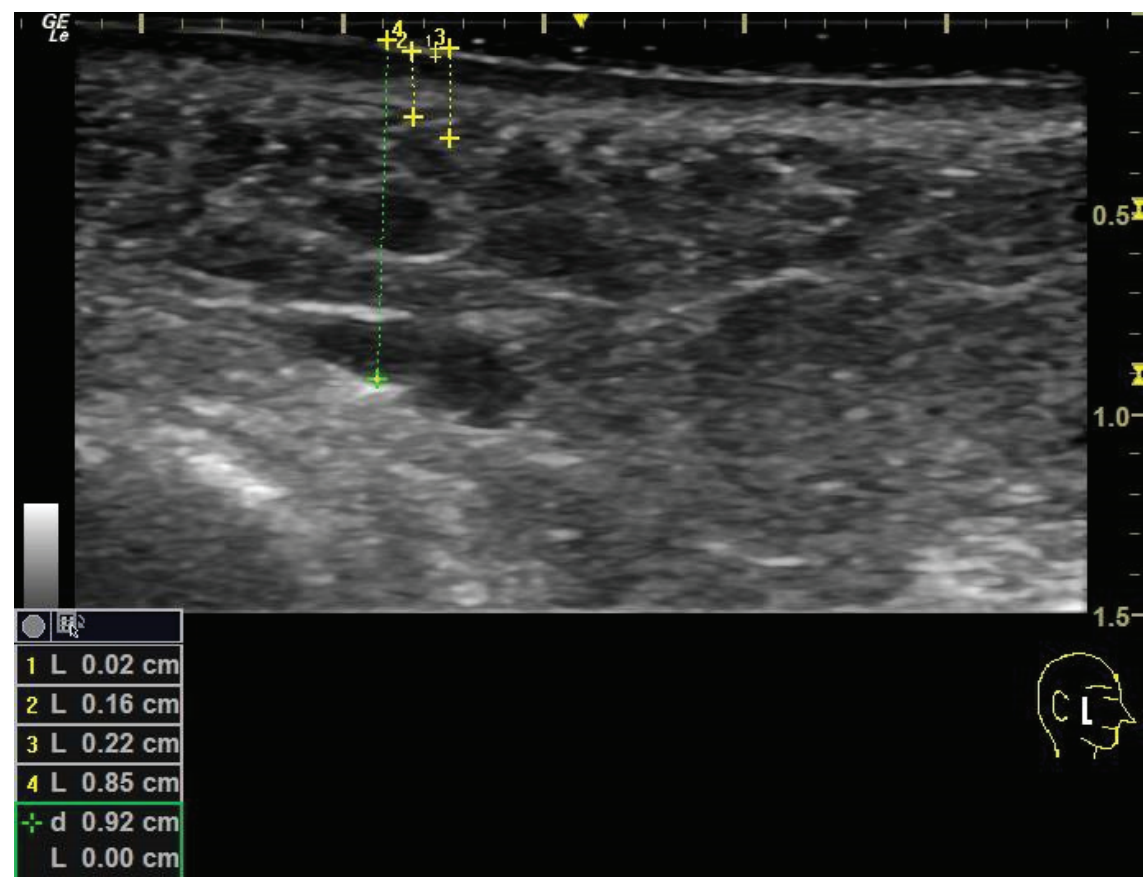

Figure 4: Screen views during ultrasound with measurements: $1=e$ idermis thickness; $2=$ dermis, including papillary dermis and Sub

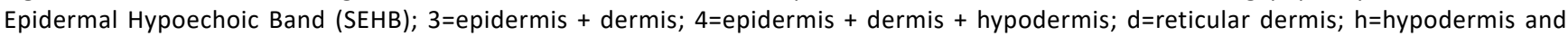
subcutaneous reticular tissue. 


\section{Conclusion}

In conclusion, it appears that the skin is thinner than what we would spontaneously believe when performing various refined injection techniques for either intradermal-mesotherapy or esthetic treatment. We may even consider that injections should be performed under ultrasound control. Nevertheless, we do not recommend this approach, with the exception for use in clinical studies, owing to the related infection issues.

\section{Acknowledgements}

The authors wish to express their warmest appreciation to the 80 subjects for kindly agreeing to participate in the study. Moreover, the authors wish to express their gratitude to Dr. C. Della Volpe for her kind permission to use her histological data in a specific manner. In addition, the authors express considerable appreciation to Dr. J.M. Martin, Montélimar-France, for his priceless assistance. Many thanks are due to Medimage Radiology Institute that placed their equipment and facilities at the authors' disposal. The authors also wish to thank GE Medical Systems, Opfikon, Switzerland, and particularly M. R. Padrun, who permitted them to use their ultrasound system and special transducer for this study and this, free of charge. Last but not least, many thanks go to Mrs. M. Ferros for selecting the subjects' images and for calculating the mean values.

\section{Author Contributions}

Micheels P had full access to the study data. As principal author, he takes full responsibility for the integrity of the data and accuracy of the data analysis, as well as for the study concept and design. Acquisition, analysis, and interpretation of data were performed by the four authors, namely Micheels P, Besse S, Rouijel J, and Viski S, with all four involved in US measurements.

All authors contributed to the data analysis, drafting, and revising the article; they all provided final approval of the version to be published and agreed to be accountable for their work.

Statistical analysis was performed by Micheels $P$.

Administrative, technical, and material support was provided by Micheels P.

\section{Study supervision was performed by Micheels $\mathrm{P}$.}

\section{Funding}

This study received no financial support and was resourced by the authors themselves, except for the ultrasonography machine that the authors were enabled to employ free of charge at General Electric (GE) Medical Systems, Switzerland.

\section{Conflicts of Interest}

Patrick Micheels, MD, has worked as a consultant and trainer for Allergan, Antéis, Merz, Galderma, Q-Med, Teoxane, and Vivacy. The other authors have no conflicts of interest to disclose.

\section{References}

1. Pistor M (1976) Abrégé de mésothérapie pratique. Paris, Maloine 149.

2. Bonnet $\mathrm{CH}$, Mrejen D, Perrin JJ (2003) La mésothérapie en médecine esthétique et médecine générale. $4^{\text {th }}$ Edition, Limay, Mésodiffusion.

3. Micheels P, Sarazin D, Besse S, Sundaram H, Flynn TC (2013) A blanching technique for intradermal injection of the hyaluronic acid Belotero. Plast Reconstr Surg 132: 59S-68S.

4. Tran C, Carraux P, Micheels P, Kaya G, Salomon D (2014) In vivo bio-integration of three hyaluronic acid fillers in human skin: a histological study. Dermatology 228: 47-54.

5. Micheels P, Besse S, Flynn TC, et al. (2014) Etude échographique comparative de la diffusion de 3 gels d'acide hyaluronique de comblement de rides "FDA approved", lors d'injections intradermiques superficielles et moyennes. J Med Esthet Chir Derm 162: 95-100.

6. Bonnet $\mathrm{CH}$, Laurens D, Perrin JJ (2008) Guide pratique de la mésothérapie. Paris: Masson 1-2.

7. Gupta V, Sharma VK (2019) Skin typing: Fitzpatrick grading and others. Clin Dermatol 37: 430-436.

8. Caggiati A (2016) Ultrasonography of Skin Changes in Legs with Chronic Venous Disease. Eur J Vasc Endovasc Surg 52: 534-542.

9. Della Volpe C, Andrac L, Casanova D, Legré R, Magalon G (2012) Skin diversity: histological study of 140 skin residues, adapted to plastic surgery. Ann Chir Plast Esthet 57: 423-449.

10. Aubry S, Casile C, Humbert P, Jehl J, Vidal C, et al. (2009) Feasibility study of 3-T MR imaging of the skin. Eur Radiol 19: 1595-1603.

11. Bittoun J, Querleux B, Darasse L (2006) Advances in MR imaging of skin. NMR Biomed 19: 723-730.

12. Micheels P, Goodman L (2018) Injection Depth in Intradermal Therapy: Update and Correction of Published Data. J Drugs Dermatol 17: 88-96. 